\title{
APRESENTAÇÃO DA EDITORA DESTE NÚMERO
}

\author{
Comente este artigo no blog Ebibli = http://encontros-bibli-blog.blogspot.com/
}

No mundo de Babel em que vivemos não falamos uma mesma língua, mesmo quando nos expressamos através do mesmo idioma. Nesta obscura torre, onde o homem se manifesta pelas linguagens que constituiu, muitos são os modos como individualmente um sujeito compreende o que está implícito e explicito na teia de sentidos que foi cuidadosamente constituída e articulada para expressar significado.

Dewey, ao constituir seu sistema de classificação, afirmou ser ele um construto para educação do individuo embora entendesse ser necessário "[...] saber como extrair sentido da página impressa". De fato, independente do suporte onde se exibe, uma mensagem para se tornar um lance de comunicação, precisa ser assimilada, demandando que dela se extraia os sentidos que manifesta.

Este desafio aproximou a Semiótica da Ciência da Informação uma vez que ambas buscam consolidar algo essencial para minimizar os impactos da obesidade de informação que se vivencia hoje, qual seja, promover acesso ao significado dos artefatos de cultura produzidos pelo homem de modo a fomentar saberes que constituam conhecimentos ou, como afirma Maria Aparecida Moura, no artigo Ciência da Informação e Semiótica: conexão de saberes, ambas procuram ampliar a compreensão das manifestações de modo a conectar conhecimento e sabedoria.

Nesta perspectiva, a aproximação inicialmente ocorreu pelo foco que, aparentemente lhes é mais próximo, o das linguagens documentárias e suas semioses, como questiona Marilda Lopes Ginez de Lara, no artigo É possível falar em signo e semiose documentária?

Assim exposta, tal aproximação da Semiótica com a Ciência da Informação ocorreu através das duas abordagens mais conhecidas da primeira: a corrente fenomenológica do americano Charles Sanders Peirce e a lingüística do lituano-francês Algirdas Julien Greimas, embora minimamente exista ainda a vertente russa da Escola de Tartu, representada por Iuri Lotman.

Os estudos da linha americana também se manifestam na discussão de Solange Silva Moreira, no artigo $O$ icone e a possibilidade de informação que trata da potencialidade informacional do ícone, elemento onde se circunscreve a lógica das articulações teóricas que devem ser estabelecidas pela aproximação acima tratada.

A abordagem é recorrente no texto de Silvana Drumond Monteiro que, ao expor sua Semiótica peirciana e a questão da informação e do conhecimento apresenta a diferença entre informação e conhecimento, tanto do ponto de vista da linguagem, como do sujeito cognoscente.

No artigo Signos audiovisuais e ciência da informação: uma avaliação, Jalver Bethônico também se ampara nas reflexões de Charles Sanders Peirce para concluir pela compreensão do fenômeno da informação através da análise nos mais variados tipos de textos que são materializados em distintas formas simbólicas destacando que o saber é ato de conhecer sob o ponto de vista daquele que o interpreta.

$\mathrm{Na}$ expectativa de oferecer um outro foco para a parceria da Ciência da Informação com a Semiótica, Celia Regina Simonetti Barbalho, no texto Fazer semiótico: subsídios para 
exame do espaço concreto, expõe os aspectos teóricos da abordagem francesa e estabelece o espaço enquanto locus de suas análises.

Neste conjunto de artigos, será possível observar o quão variada é a análise semiótica e o quanto ela pode oferecer para o entendimento da informação enquanto um instrumento capaz de favorecer a percepção do homem em seu contexto e promover sua capacidade de articulação com o mundo que o cerca.

A intencionalidade de se consolidar esta Edição Especial ocorreu no sentido de permitir que se instale, mais intensamente, no contexto dos estudos brasileiros que buscam tal interface, uma ampla discussão que permita disseminar os fundamentos de uma área de árdua compreensão, como é a semiótica, de modo a consentir que a tênue relação existente entre as áreas, possa contribuir para uma percepção ampla do modo de entender os artefatos de cultura postos para serem visíveis ao olhar de um outro, ator do contexto onde a informação busca sua transformação em conhecimento.

Profa. Dra. Célia Regina Simonetti Barbalho

Universidade Federal do Amazonas.

Amazonas, Brasil

Novembro de 2006 